\title{
The response of primary producer assemblages to mitigation measures to reduce eutrophication in a temperate estuary
}

\author{
S. Leston ${ }^{\text {a,* }}$, A.I. Lilleb $\emptyset^{\text {b }}$, M.A. Pardal ${ }^{\text {a }}$ \\ ${ }^{\text {a } I M A R}$ - Institute of Marine Research, Department of Zoology, University of Coimbra, 3004-517 Coimbra, Portugal \\ ${ }^{\mathrm{b}}$ CESAM - Centro de Estudos do Ambiente e do Mar, University of Aveiro, Campus de Santiago, $3810-193$ Aveiro, Portugal
}

Received 18 July 2007; accepted 13 November 2007

Available online 19 November 2007

\begin{abstract}
The Mondego estuary is a well-described system located on the North Atlantic Ocean, where cultural eutrophication progressed over the last decades of the 20th century. Consequently, and due to a large productivity of Ulva spp., Zostera noltii meadows were severely reduced with a concomitant decrease in environmental quality. In 1998, experimental mitigation measures were implemented, via changes in hydrology to increase circulation and diversion of nutrient-rich freshwater inflow, to reverse the process in the most affected area of the estuary - its South arm.

The objective of this study was to assess the differences in response of primary producer assemblages to the implemented measures to reduce eutrophication.

Results show that the mean concentrations of DIN suffered a notorious decrease due to a significant reduction in the ammonium concentration in the water column, while DIP increased significantly. Primary producer assemblages showed different responses to these changes: phytoplankton, measured as concentration of chlorophyll $a$, did not show any significant changes; green macroalgae, mostly Ulva spp., suffered a large reduction in biomass, whereas Gracilaria gracilis and the macrophyte Zostera noltii biomasses increased greatly. Results show that phytoplankton biomass has remained constant and suggest that the reduction in ammonium could have been responsible for the changes in the green macroalgal biomass. Light was the most likely factor in the response of seagrass whereas red macroalgal reaction seemed to be dependent on both light and ammonium.
\end{abstract}

(C) 2007 Elsevier Ltd. All rights reserved.

Keywords: Zostera noltii; Ulva; Gracilaria; nitrogen; phosphorus; eutrophication

\section{Introduction}

In estuarine systems, plant communities are constituted by complex assemblages of phytobenthos and phytoplankton, each with different access to nutrients and light (Taylor et al., 1995) that can constitute potentially limiting factors to the primary production of these aquatic autotrophs (Pedersen and Borum, 1992). Phytoplankton and fast-growing ephemeral macroalgae are often limited by nutrient availability, while slow-growing perennial macroalgae and rooted macrophytes

\footnotetext{
* Corresponding author.

E-mail address: saraleston@ci.uc.pt (S. Leston).
}

seem less dependent on nutrient concentrations (Sand-Jensen and Borum, 1991).

In the last decades, anthropogenic activities have enhanced the enrichment of water bodies with nutrients, particularly nitrogen and phosphorus, named as "cultural eutrophication". Agricultural run-off, waste discharges from industries and fish farms amongst others are responsible for nutrient inputs into aquatic systems (Menéndez and Comín, 2000; Hernández et al., 2002; Nedwell et al., 2002).

Phytoplankton and macroalgae are capable of taking advantage of the available resources in transient environments (Viaroli et al., 1996; Raven and Taylor, 2003; Cohen and Fong, 2004). Their high surface area to volume ratio and high affinity for nutrients, especially $\mathrm{N}$ and $\mathrm{P}$, favor a rapid 
nutrient uptake and high growth and production rates leading to very large biomass values (Rosenberg and Ramus, 1984; Hernández et al., 1997; Raffaelli et al., 1998; Raven and Taylor, 2003). Among the macroalgal species found in areas undergoing eutrophication are the genus Chaetomorpha, Cladophora, Gracilaria and Ulva (Raffaelli et al., 1998; Mistri et al., 2001; Fong et al., 2004). By influencing benthic nutrient processes through interception of light and water column nutrients (Boyer and Fong, 2005), they often out-compete other species, usually late-successional, long-lived species like perennial macroalgae (e.g. Fucus) and seagrass (e.g. Zostera) (Peckol and Rivers, 1996; Menéndez and Comín, 2000).

Seagrass are important primary producers in estuarine systems and their abundance and distribution are strongly correlated with light availability (Kraemer and Hanisak, 2000). Eutrophication effects on seagrass meadows are stronger in sheltered environments with frequent and high nutrient loadings, reduced tidal flushing and fluctuating temperatures (Maier and Pregnall, 1990). Increased nitrogen loading has been pointed out as an important cause of seagrass loss by stimulating competition for available light (e.g. van Katwijk et al., 1997; Brun et al., 2002; Valiela and Bowen, 2007).

Due to the unique importance of seagrass meadows in the ecosystems, it is necessary to take measures to minimize and revert the effects of eutrophication, bringing the systems into the previous stable state (e.g. Webster and Harris, 2004). However, to guarantee that the restoration programmes are successful, it is important to understand the mechanisms that have led to the ecological changes (Zhang et al., 2003). In the case of macroalgal blooms, the knowledge of their responses to changes in their driving variables (e.g. nutrient loadings, hydrodynamics) is essential to understand the way the system will react and thus assuring its recovery (e.g. Webster and Harris, 2004).

The Mondego estuary is a temperate, intertidal ecosystem that has been for the last decades under ecological stress caused mainly by eutrophication. Overall the system presented itself with a severe decrease in environmental quality (Lillebø et al., 2007; Teixeira et al., 2007), and to revert this condition, in 1998, a management plan was implemented with measures that included the reduction of nutrient load to the system South arm, the increase in hydrodynamics in order to reduce the water residence time and the physical protection of the seagrass meadows (for further information see Lillebø et al., 2005).

The aim of the present study was to assess the response of phytoplankton (accessed as concentration of chlorophyll $a$ ), the macroalgae Ulva spp. and Gracilaria gracilis and the seagrass Zostera noltii (Hornem) to the mitigation measures implemented in the Mondego estuary to reduce the eutrophication symptoms.

\section{Material and methods}

\subsection{Study area}

The Mondego estuary is located on the Western Coast of Portugal $\left(40^{\circ} 08^{\prime} \mathrm{N} ; 8^{\circ} 50^{\prime} \mathrm{W}\right)$, with an approximate area of
1072 ha and $7 \mathrm{~km}$ long, characterized by a temperate coastal climate with Mediterranean and Atlantic influences. It comprises two arms, North and South, separated by an alluviumformed island (Murraceira Island) that joins again near the mouth. The North arm of the sea is deeper (4-8 m during high tide, tidal range $1-3 \mathrm{~m}$ ), while the South arm is shallower (2-4 $\mathrm{m}$ during high tide, tidal range $1-3 \mathrm{~m}$ ) and until 1998 it was largely silted up in the upstream areas, which caused freshwater to flow mainly through the North arm. As a consequence, water circulation was dependent on tides and freshwater discharges (which constituted an important input of nutrients) from a small tributary, the Pranto River (Fig. 1).

In 1998, a restoration program was implemented to reverse the process of eutrophication in the most affected area of the estuary - the South arm (Fig. 1), comprising several measures. To reduce the loadings of nutrients into the South arm from the Pranto River the sluice aperture was reduced and most of the freshwater flow from this tributary was diverted to the North arm by another sluice located upstream. To improve water circulation the connection between both arms was enlarged allowing water to flow from the North arms during high tide. The remainder of the seagrass patches was delimited by wooden stakes to prevent physical disturbance and awareness meetings were held to inform the population about the importance of these areas (for more detailed description see Lillebø et al., 2005, 2007).

The summary of the main characteristics of the South arm of the estuary is presented in Table 1.

\subsection{Field program and laboratory procedures}

The study was conducted between February 1993 and December 2004 in the South arm of the Mondego estuary, as a part of a long-term monitoring program. Three sites ( $a$, $b$ and $c-$ Fig. 1A) were selected based on macroalgal abundance following a preoperational gradient increasing from downstream to upstream. The distance between sites $a$ and $b$ is $0.25 \mathrm{~km}$ and between $b$ and $c$ is $0.5 \mathrm{~km}$. Originally the three sites were covered by rooted macrophytes but as eutrophication increased, together with human disturbance, Zostera noltii declined progressively, being currently restricted to site $a$ (Fig. 1B).

Sampling was carried out almost each 2 months from February 1993 until December 2000 and monthly thereafter. From January 1997 to December 1998 no sampling was performed. On each sampling occasion, water temperature and salinity were recorded in situ. The water samples collected (approximately $250 \mathrm{ml}$ ) were stored, filtered through pre-combusted ( $3 \mathrm{~h}$ at $500{ }^{\circ} \mathrm{C}$ ) $\mathrm{GF} / \mathrm{C}$ filters (Whatman) in acid-washed polythene bottles at $-18{ }^{\circ} \mathrm{C}$ until further analysis. Nitrate $\left(\mathrm{NO}_{3}-\mathrm{N}\right)$ and nitrite $\left(\mathrm{NO}_{2}-\mathrm{N}\right)$ were analysed according to standard methods described in Strickland and Parsons (1972) and ammonium $\left(\mathrm{NH}_{4}-\mathrm{N}\right)$ and phosphate $\left(\mathrm{PO}_{4}-\mathrm{P}\right)$ analysis followed the Limnologisk Metodik (1992) methodology. The phytoplankton chlorophyll $a(\mathrm{Chl} a)$ determinations were performed by filtering $0.5-1.0 \mathrm{~L}$ of water through Whatman $\mathrm{GF} / \mathrm{C}$ glassfibre filters followed by extraction according to Parsons et al. 

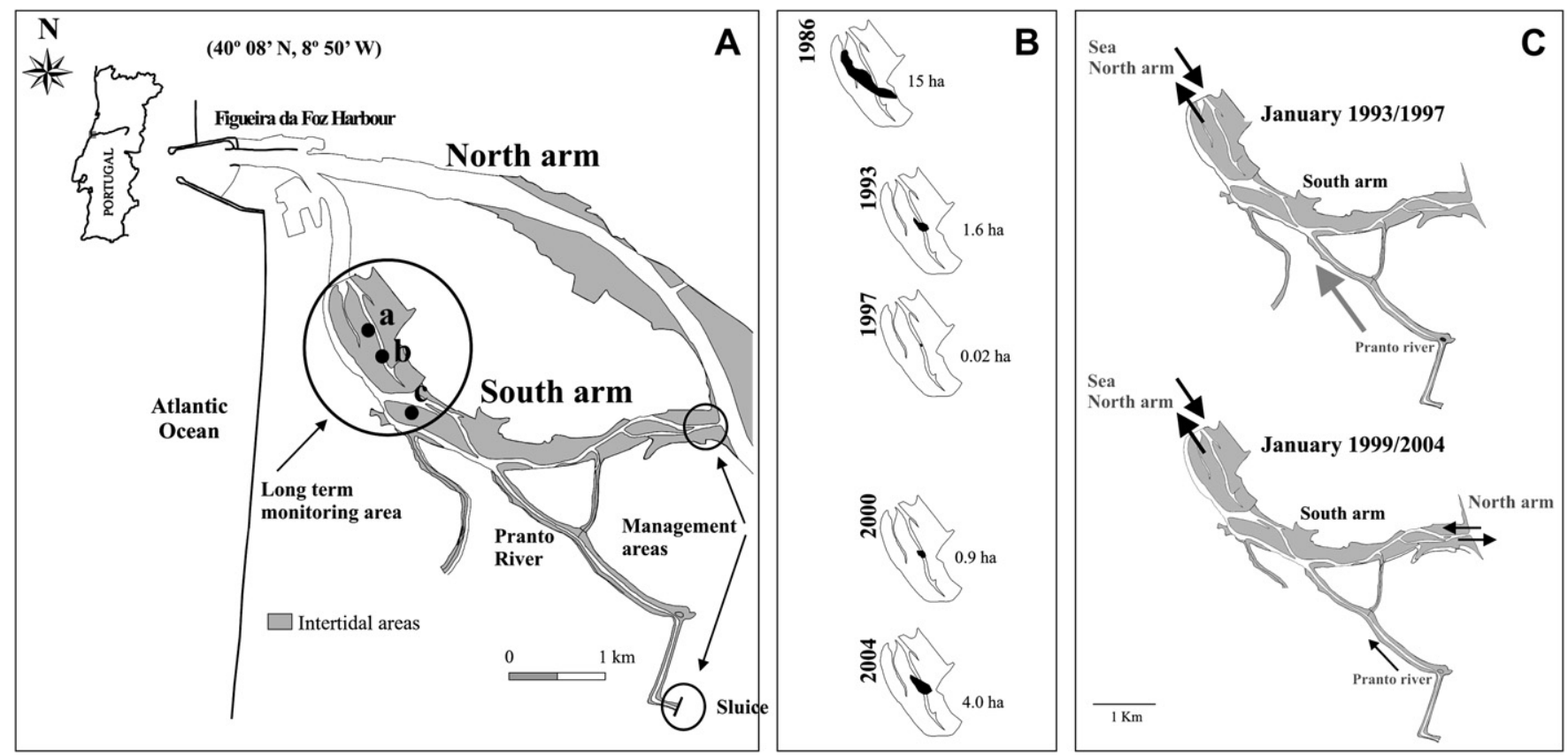

Fig. 1. (A): the Mondego estuary, with the location of the long-term monitoring area ( $a, b$ and $c$ represent a gradient of eutrophication where $c$ is the most eutrophicated area) and the areas where mitigation measures were implemented; (B): the evolution of the Z. noltii beds (ha) from 1986 to 2004, showing the drastic reduction from 1993 to 1997 and the recovery after 1998; (C): the main freshwater inputs before the management (1993-1997) and after (1999-2004). The black arrows represent saltwater and grey arrows represent freshwater flows into the system and their length indicates the intensity of the flow.

(1985). In the field and during transportation to the laboratory, samples were stored on ice and protected from light. Samples from the three monitoring areas $(a, b$ and $c)$ were collected and analysed separately. Due to the small distance between sites, data relating to the water column were put together and presented/related as mean values $( \pm \mathrm{SE})$ for the South arm of the estuary.

Plant sampling for biomass assessment was performed haphazardly with a corer (minimum six cores, with $143 \mathrm{~cm}^{2}$ section) and biomass determined as ash free dry weight (AFDW) after oven drying at $60^{\circ} \mathrm{C}$ for $72 \mathrm{~h}$ and combustion at $450{ }^{\circ} \mathrm{C}$ for $8 \mathrm{~h}$.

Macroalgae and seagrass for internal nutrient content were collected at site $a$, during low tide and transported in plastic bags to the laboratory where they were rinsed, dried for $48 \mathrm{~h}$ at $60{ }^{\circ} \mathrm{C}$ until constant weight and stored dry until analysis on internal $\mathrm{N}$ and $\mathrm{P}$, in accordance to Limnologisk Metodik (1992). For phosphorus analysis, samples were combusted in

Table 1

Summary characterization of the South arm of the Mondego estuary

Characteristic

Geographic location

System intertidal area $\left(\mathrm{km}^{2}\right)$

System subtidal area $\left(\mathrm{km}^{2}\right)$

System volume $\left(10^{6} \mathrm{~m}^{3}\right)$

Mean depth (m)

Tidal range $(\mathrm{m})$

Mixing characteristics

Mean substratum composition

Annual insolation of PAR

$(400-700 \mathrm{~nm})\left(\mathrm{mol}\right.$ phot. $\left.\mathrm{m}^{-2} \mathrm{y}^{-1}\right)$

Salinity range

Mean water temperature range $\left({ }^{\circ} \mathrm{C}\right)$

Residence time

Current velocity

Turbidity

DIN (mean) $\left(\mu \mathrm{mol} \mathrm{L}^{-1}\right)$

DIP (mean) $\left(\mu \mathrm{mol} \mathrm{L}^{-1}\right)$

$\mathrm{N} / \mathrm{P}$ (mean)

$40^{\circ} 08^{\prime} \mathrm{N}, 8^{\circ} 50^{\prime} \mathrm{W}$

1.75

0.96

2-4 high tide

$0.35-3.3$

Well-mixed with irregular river discharges

Silt, clay and sand

3200-32,000

1993-1997 (Before management)

1.9-33.1

8.0-23.7

Moderate (weeks)

Low and dependent on the Pranto River sluice High

35.59

1.01

35.09
1999-2004 (After management)

$0.2-33.7$

$8.1-22.1$

Short (days)

Higher and not dependent on the Pranto River sluice Lower

14.52

1.59

9.13 
a muffle furnace at $500{ }^{\circ} \mathrm{C}$ for $3 \mathrm{~h}$. All samples were homogenized prior to analysis.

\subsection{Statistical analysis}

The long-term data were analysed for significant changes before (1993-1997) and after the management (1999-2004) using the STATISTICA ${ }^{\mathrm{TM}}$ software (StatSoft Inc., 2001; version 6.0). Although the sets of data passed the Equal Variance Test, the Normality Test failed for all of the groups and for that reason the non-parametric Mann-Whitney Rank Sum Test was used to determine if the changes observed between both periods had statistical relevance.

\section{Results}

\subsection{Nutrient concentration}

Table 2 shows the changes in the nutrient concentrations present in the water column during the study period. The total dissolved inorganic nitrogen (TDIN) in the water column was lowered mostly due to the reduction of ammonium inputs, since the concentration of the oxidized forms $\left(\mathrm{NO}_{3}-\mathrm{N}\right.$ and $\mathrm{NO}_{2}-\mathrm{N}$ ) remained constant (n.s.: $T=316.0 ; \quad P=0.602$ ) throughout the years (Table 2). The reduced form presented a mean value of $28.9 \mu \mathrm{mol} \mathrm{L}^{-1}$ prior to 1998 which dropped to $7.76 \mu \mathrm{mol} \mathrm{L}^{-1}$ afterwards (Table 2), with a statistically significant decrease (significant: $T=44.0 ; P=0.002$ ). Before the management actions, ammonium was the predominant form in the estuary about four times more abundant than the oxidized forms, but afterwards the ratio reduced:oxidized became 1:1.

The dissolved inorganic phosphorus (DIP) increased significantly (significant: $T=147.0 ; P=0.013$ ) from a mean value of $1.01 \mu \mathrm{mol} \mathrm{L}^{-1}$ to $1.59 \mu \mathrm{mol} \mathrm{L}^{-1}$ (Table 2).

\subsection{Primary producers' biomass}

The responses of the potentially opportunistic primary producers (chlorophyll $a$ concentration and macroalgal biomass) for the two distinctive periods were different and are presented in Fig. 2. Phytoplankton data (concentration of chlorophyll $a$, Fig. 2A) are mean values for the three sites. To best describe the variations in biomass of macroalgae and seagrass, data were not presented as mean values. Instead, Ulvaceans biomass is described with data from site $c$, where they were continuously present throughout the study period (Fig. 2B).

Table 2

The water column nutrients concentrations $\left(\mu \mathrm{mol} \mathrm{L}^{-1}\right)$ in the pre-management (1993-1997) and post-management (1999-2004) periods. SE is the standard error

\begin{tabular}{|c|c|c|c|c|c|c|c|c|}
\hline & \multicolumn{4}{|c|}{$1993-1997$} & \multicolumn{4}{|c|}{ 1999-2004 } \\
\hline & Min & $\operatorname{Max}$ & Mean & SE & Min & $\operatorname{Max}$ & Mean & SE \\
\hline $\mathrm{NO}_{x}-\mathrm{N}\left(\mu \mathrm{mol} \mathrm{L}{ }^{-1}\right)$ & 0.50 & 38.93 & 7.13 & 0.16 & 0.74 & 36.06 & 6.98 & 0.14 \\
\hline $\mathrm{NH}_{4}-\mathrm{N}\left(\mu \mathrm{mol} \mathrm{L}^{-1}\right)$ & 7.58 & 84.29 & 28.15 & 0.38 & 1.2 & 15.87 & 7.76 & 0.06 \\
\hline $\mathrm{PO}_{4}-\mathrm{P}\left(\mu \mathrm{mol} \mathrm{L}^{-1}\right)$ & 0.44 & 2.02 & 1.01 & 0.01 & 0.20 & 3.06 & 1.59 & 0.01 \\
\hline
\end{tabular}
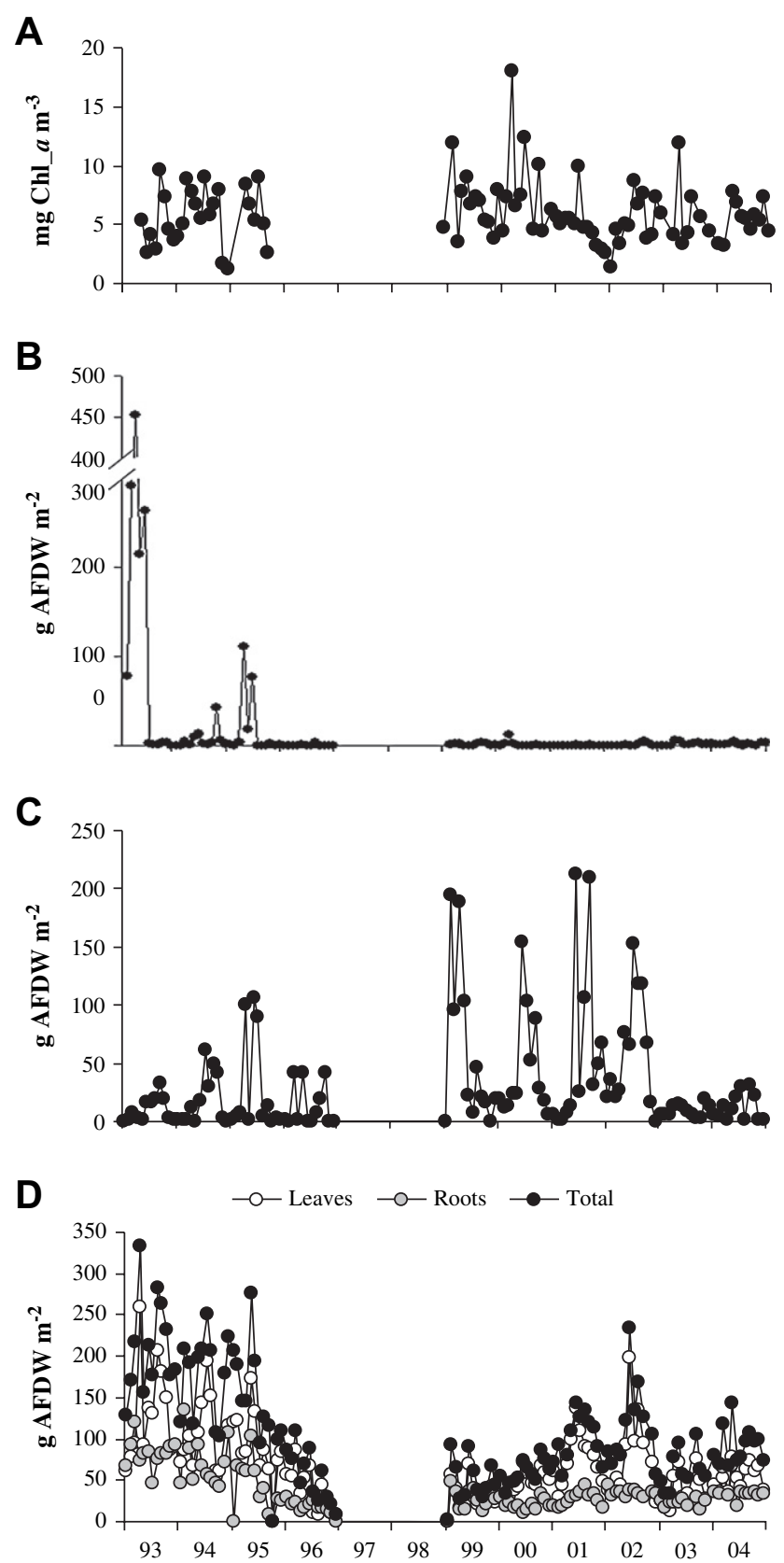

Fig. 2. The inter-annual variation of primary producers assemblages before (1993-1997) and after the management (1999-2004): (A): phytoplankton; (B): Ulva spp. biomass; (C): Gracilaria gracilis biomass; (D): Z. noltii biomass.

Gracilaria gracilis' presence, on the other hand, was intermittent at sites $b$ and $c$ but continuous at site $a$ and for that reason data from this site were used (Fig. 2C). Zostera noltii was only present at site $a$ (Fig. 2D).

Chlorophyll $a$ concentrations (Fig. 2A) did not differ significantly $(T=1120.5, P=0.831)$ between the two periods (Table 3).

With respect to macroalgae, the green species identified were Ulva compressa (L.) Greville and Ulva intestinalis (L.) Link (according to revision by Hayden et al., 2003) and the red macroalgae was Gracilaria gracilis. Ulvaceans presented 
Table 3

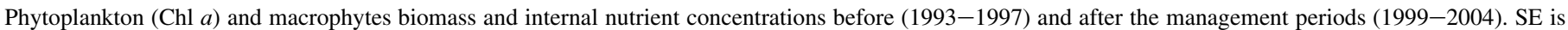
the standard error

\begin{tabular}{|c|c|c|c|c|c|c|c|c|c|}
\hline & & \multicolumn{4}{|c|}{$1993-1997$} & \multicolumn{4}{|c|}{ 1999-2004 } \\
\hline & & Min & Max & Mean & SE & Min & Max & Mean & SE \\
\hline Chl $a\left(\mathrm{mg} \mathrm{m}^{-3}\right)$ & Phytoplankton & 1.20 & 20.97 & 6.80 & 0.91 & 1.43 & 18.05 & 6.12 & 0.04 \\
\hline \multirow[t]{4}{*}{ Biomass ( $\mathrm{g} \mathrm{m}^{-2}$ AFDW) } & Ulva spp. & 0.00 & 452.23 & 34.66 & 13.06 & 0.00 & 12.63 & 1.52 & 0.24 \\
\hline & Gracilaria gracilis & 0.00 & 105.9 & 17.63 & 2.50 & 0.00 & 213.27 & 41.14 & 6.40 \\
\hline & Zostera noltii roots & 0.00 & 135.57 & 54.90 & 4.89 & 1.93 & 66.63 & 28.43 & 1.33 \\
\hline & Zostera noltii leaves & 0.00 & 258.81 & 91.25 & 7.94 & 0.06 & 197.90 & 55.01 & 3.88 \\
\hline \multirow{4}{*}{$\begin{array}{l}\text { Tissue nitrogen } \\
\left(\mathrm{mg} \mathrm{g}^{-1} \mathrm{DW}\right)\end{array}$} & Ulva spp. & 32.88 & 95.61 & 62.02 & 0.40 & 16.55 & 112.89 & 52.83 & 3.15 \\
\hline & Gracilaria gracilis & 24.64 & 110.04 & 62.42 & 3.02 & 19.34 & 108.81 & 58.5 & 0.52 \\
\hline & Zostera noltii roots & 11.56 & 45.56 & 23.92 & 2.85 & 3.37 & 47.42 & 19.14 & 1.91 \\
\hline & Zostera noltii leaves & 19.47 & 64.08 & 37.10 & 3.72 & 6.05 & 45.37 & 29.54 & 1.45 \\
\hline \multirow{4}{*}{$\begin{array}{l}\text { Tissue phosphorus } \\
\quad\left(\mathrm{mg} \mathrm{g}^{-1} \mathrm{DW}\right)\end{array}$} & Ulva spp. & 1.19 & 5.54 & 2.18 & 7.51 & 0.29 & 3.87 & 2.04 & 0.12 \\
\hline & Gracilaria gracilis & 1.23 & 2.88 & 2.08 & 0.05 & 0.05 & 6.23 & 2.25 & 0.03 \\
\hline & Zostera noltii roots & 1.26 & 6.85 & 3.09 & 0.40 & 0.62 & 8.67 & 4.51 & 0.37 \\
\hline & Zostera noltii leaves & 1.83 & 4.46 & 2.55 & 0.25 & 1.84 & 9.25 & 5.61 & 0.36 \\
\hline
\end{tabular}

a very high biomass (Fig. 2B), with maximal densities of $452.23 \mathrm{~g} \mathrm{AFDW} \mathrm{m}^{-2}$ and a mean value of $34.66 \mathrm{~g} \mathrm{AFDW} \mathrm{m}^{-2}$ (Table 3), before the management actions were implemented. However, after 1998 green macroalgae showed a significant decrease in biomass $(T=2754.5, P<0.05)$, with the mean value dropping to $1.52 \mathrm{~g} \mathrm{AFDW} \mathrm{m}^{-2}$ (Table 3 ). On the other hand, G. gracilis biomass increased greatly $(T=1984.5$, $P<0.001$ ) (Fig. 2C). The highest value reported in the premanagement period was $105.9 \mathrm{~g} \mathrm{AFDW} \mathrm{m}^{-2}$, with a mean value of $17.12 \mathrm{~g} \mathrm{AFDW} \mathrm{m}^{-2}$ but afterwards it increased to $195.3 \mathrm{~g} \mathrm{AFDW} \mathrm{m}^{-2}$ with a mean of 40.76 (Table 3). Zostera noltii meadows were dramatically reduced from an approximate area of $150,000 \mathrm{~m}^{2}$ in 1986 to $200 \mathrm{~m}^{2}$ in 1997 (Fig. 1B). Aboveground biomass suffered a drastic reduction between 1993 and 1997, but after 1999 it began to recover (Fig. 2D). However, the maximum biomass value for the post-management period $\left(234.89 \mathrm{~g} \mathrm{AFDW} \mathrm{m}^{-2}\right)$ is still inferior to the maximum value of $333.06 \mathrm{~g} \mathrm{AFDW} \mathrm{m}^{-2}$ presented before the management. Zostera noltii aboveground and belowground biomass have shown significant differences ( $T=3021.0, \quad P<0.05 ; T=3204.0, P<0.05$, respectively) (Table 3) revealing an increasing tendency.

\subsection{Seasonal growth pattern}

Phytoplankton presented a seasonal variation throughout the study period, with chlorophyll increase in late winter/early spring, reaching a peak in mid summer and decreasing afterwards (Fig. 3A). The Ulvaceans biomass showed two distinct annual patterns. In 1993 and 1995, when large blooms of Ulva spp. occurred, growth began in late winter/early spring, with two peaks of biomass in mid spring and a subsequent decay in mid summer (Fig. 3B). In years with lower biomass, the pattern of growth of Ulva spp. often presented two peaks of biomass, one in mid spring and another in late summer/autumn (Fig. 3B). Gracilaria gracilis exhibited only one pattern of growth prevailing during the study period. Biomass production started in late winter, continuing throughout spring and reaching a peak in summer (Fig. 3C). In autumn, biomass decreased but red macroalgae continued to be present all year round. Zostera noltii also exhibited a seasonal pattern of biomass production (Fig. 3D). Aboveground biomass increased mostly during the spring and summer, whereas the belowground biomass increased in autumn and winter.

\subsection{Tissue nutrient concentrations}

When considering the tissue $\mathrm{N}$ and $\mathrm{P}$ of green macroalgae throughout the study period, no statistically significant differences were found $(T=221.5, P=0.492$ for $\mathrm{N} ; T=188.5$, $P=0.788$ for P). The same situation was observed in Gracilaria gracilis $(T=289.5, P=0.844$ for $\mathrm{N} ; T=244.0$, $P=0.438$ for P). Macroalgae kept the internal nutrients' concentrations constant and with values within the same range (Table 3). Regarding Zostera noltii, the nitrogen content of the roots was not significantly different between the two periods $(T=1.411, P=0.166)$, whereas nutrient content in leaves decreased significantly $(T=2.310, P<0.05)$ from a mean value of 37.1 to $29.5 \mathrm{mg} \mathrm{g}^{-1}$ (Table 3). The internal phosphorus content increased significantly both in roots $(T=-5.126, P<0.001)$ and leaves $(T=2.343, P<0.05)$ (Fig. 4).

The analysis of the percentage of dry weight (\% DW) in tissue nutrient concentrations allowed to determine if there were situations of nutrient limitation. The critical nutrient content for maximum growth is defined as the internal concentration that just limits maximal growth for plants (Hanisak, 1979). It was found that both macroalgae presented $\mathrm{N}$ and $\mathrm{P}$ values well above the critical tissue concentrations for maximum growth with an exception in 2000, when heavy rains washed away nutrients, causing $\mathrm{P}$ to drop below the critical level (Fig. 4A and B). Tissue nutrient content in Zostera noltii also indicated values above the critical level for both $\mathrm{N}$ and $\mathrm{P}$ (Fig. 4C and D). In 2003, the tissue $\mathrm{N}$ content of the roots was very close to the limit but it was still above the critical level (Fig. 4C). 
A

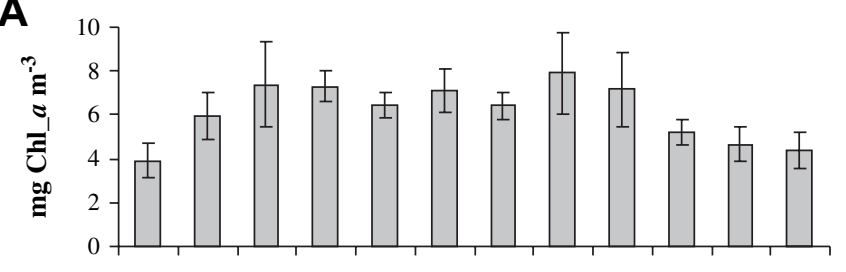

B
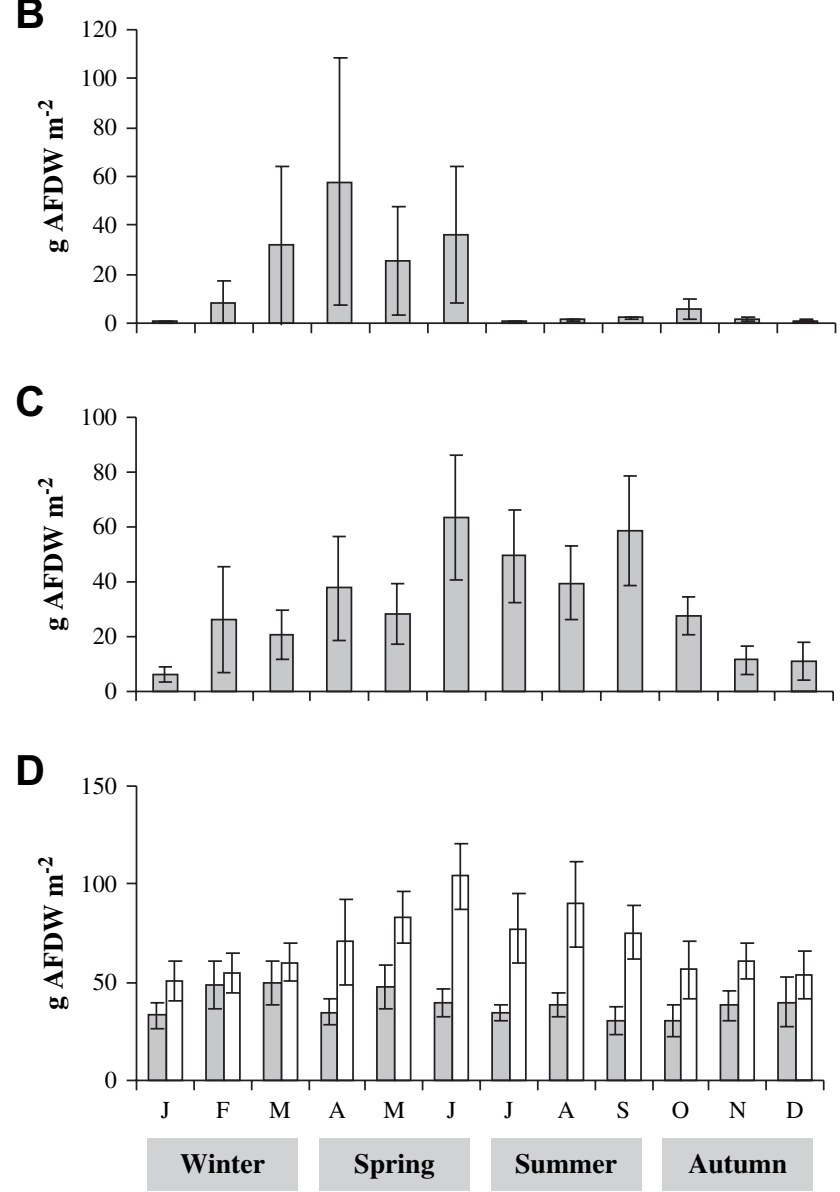

Fig. 3. The annual seasonal variation, considering the monthly means of: (A): phytoplankton; (B): Ulva spp.; (C): Gracilaria gracilis; (D): Z. noltii (grey bars representing roots biomass and the white bars represent leaves biomass), for the entire period of study ( $\pm \mathrm{SE}$, standard error).

\section{Discussion}

Several researchers have reported changes in community composition following $\mathrm{N}$ fertilization (Levine et al., 1998; Emery et al., 2001; Pennings et al., 2002). Some systems have shown a phytoplankton dominated-response (Taylor et al., 1995) while others presented macroalgal dominance (Lavery and McComb, 1991; Valiela et al., 1992). Shallow coastal estuaries with low nutrient availability in the water are more likely to be dominated by benthic algae and vascular plants due to the potential of these species to sequester nutrients from the sediments (Sand-Jensen and Borum, 1991; Havens et al., 2001). On the other hand, in systems with increased nutrient loading phytoplankton and/or macroalgae
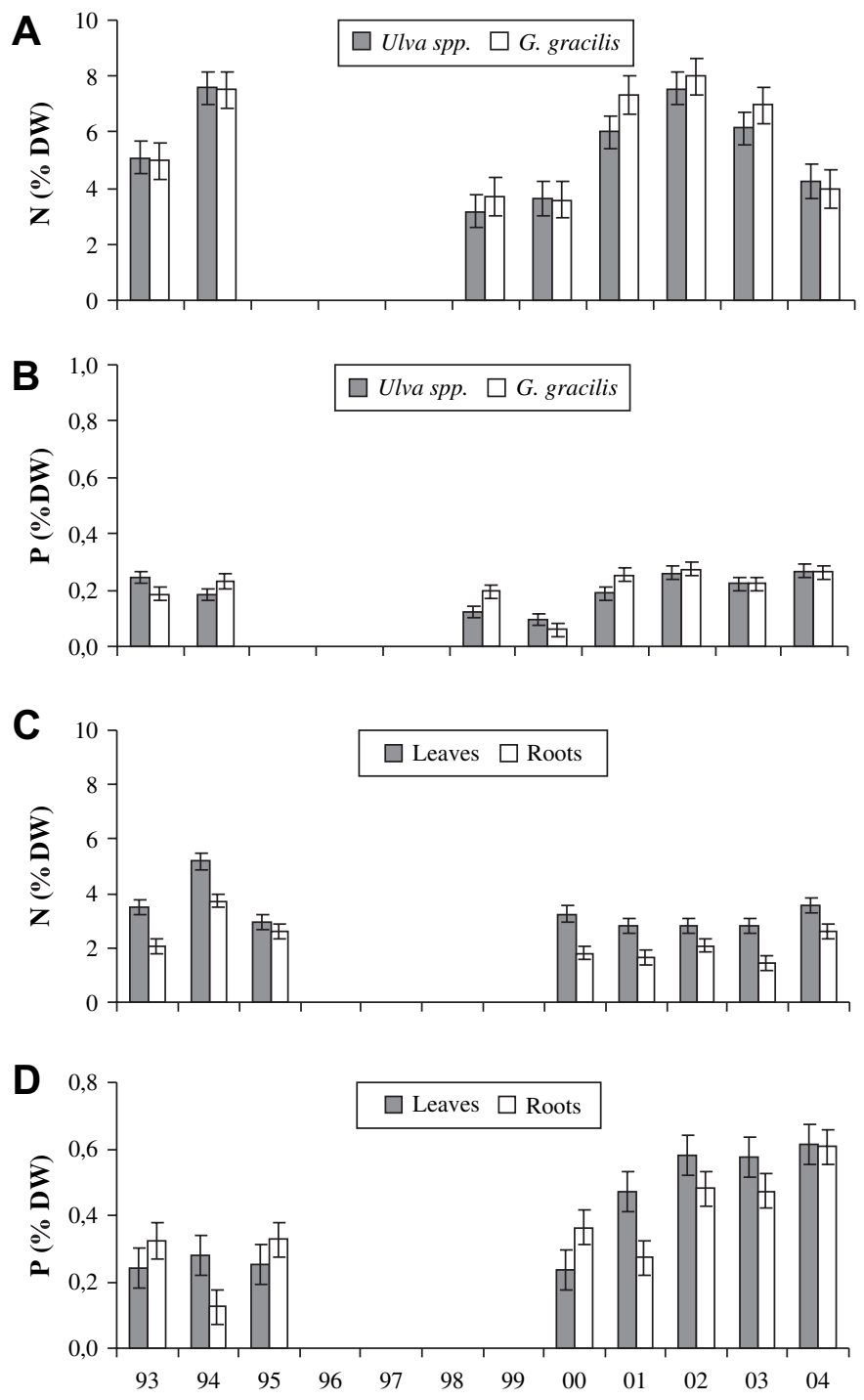

Fig. 4. The mean annual variations in the internal nutrients content as percentage of dry weight $( \pm \mathrm{SE})$, in primary producer's assemblages, before and after 1998: nitrogen (A) and phosphorus (B) in macroalgae; nitrogen (C) and phosphorus (D) in Z. noltii. The grey bar represents the critical concentration value for maximum growth under which there is nutrient limitation $(1.5 \% \mathrm{DW}$ for nitrogen and $0.13 \%$ DW for phosphorus).

will dominate over vascular plants (Sand-Jensen and Borum, 1991. Valiela et al., 1997: Havens et al., 2001).

The Mondego estuary presented changes in the primary producers assemblages resulting from the restoration actions. Macroalgae assemblages showed different trends after 1998. Ulvaceans' biomass decreased while there was a significant increase in red macroalgae (Gracilaria gracilis), leading to a shift in macroalgal dominance. A similar change in the benthic community has been reported in Sacca di Goro, in northeastern Italy, where the restriction of Ulva rigida resulted in the establishment of an almost monospecific algal cover of G. gracilis (Mistri et al., 2001). Simultaneously to the green macroalgal decrease in the Mondego's South arm, Zostera noltii slowly started to recover. Phytoplankton biomass, measured as concentration of chlorophyll $a$, did not present any 
significant changes. These differences may be explained by a combination of changes in physicochemical and hydrological factors after the implementation of the mitigation measures, namely the improvement in water circulation which reduced the water residence time and the effective reduction in nitrogen loads (Lilleb $\varnothing$ et al., 2007) specifically ammonium.

Since chlorophyll $a$ concentrations did not show any significant changes throughout the pre- and post-mitigation periods, it seems that phytoplankton biomass was not affected by the changes occurring in the system. Phytoplankton possess a lower compensation irradiance (Havens et al., 2001) and a comparatively higher surface area/volume relation that confers a higher affinity for nitrogen forms, with higher uptake rates than macroalgae for both ammonia and nitrate per unit of biomass (Hein et al., 1995; Collos, 1998). However, it is likely that there were changes in phytoplankton's composition but there is no data available to assess this.

Ulvaceans in the Mondego estuary have shown a decrease in biomass not accompanied by a decrease in internal nutrient content. In this system, the improvement of water circulation led to the increase in water flow and current velocity which in turn can lead to a higher export of floating macroalgae to the ocean (Flindt et al., 2004).

Green and red macroalgae have high affinity for ammonium and nitrate at both low and high concentrations (Fujita, 1985; Pedersen and Borum, 1997; Runcie et al., 2003) and are able to take up both forms simultaneously when they are present in the water column, but with different uptake rates (Kautsky, 1982; Pedersen and Borum, 1997; Glenn et al., 1999; Jones et al., 2001; Cohen and Fong, 2004). In Ulva spp. the uptake rate of the $\mathrm{NO}_{3}^{-}$is about one-fourth of the uptake rates found for $\mathrm{NH}_{4}^{+}$(Runcie et al., 2003). This difference may be due to the nitrate's negative charge, which makes the uptake energy-dependent and thus slower (Runcie et al., 2003). After the uptake, nitrate must be converted into ammonium in a rate-limiting step catalyzed by nitrate reductase (NR) before being accumulated in vacuoles (Viaroli et al., 1996; Cohen and Fong, 2004; Lartigue and Sherman, 2005). The level of NR in Ulva intestinalis appears to be determined by the presence or absence of $\mathrm{NO}_{3}^{-}$in the water column conferring macroalgae the ability to use a greater proportion of this nitrogen form. However, the uptake and assimilation of nitrate are energetically expensive, which could explain the preference for ammonium since it allows macroalgae to save energy (Cohen and Fong, 2004). It is possible that green macroalgae in the Mondego estuary, in order to maintain their nitrogen content, have taken up more nitrate to compensate the decrease in ammonium. Fong et al. (2004) hypothesized that Ulva spp. have evolved mechanisms to take advantage of high concentrations of nitrogen by prioritising allocation of available energy and carbon skeletons to nutrient uptake and assimilation of N. Turpin et al. (1988) described increased respiration rates and use of fixed carbon to synthesize amino acids following the addition of $\mathrm{NO}_{3}^{-}$. This difference in uptake may have reduced the energy available and, as a result, maximum growth was not attained, even when the other environmental factors were favorable.
The changes in the nitrogen forms seem to have affected red macroalgae differently. Red macroalgae are especially efficient at taking up nutrients rapidly and, unlike Ulvaceans, have mechanisms to store large reserves of nitrogen (Jones et al., 2001; Menéndez et al., 2001; Hernández et al., 2006) in the red pigment phycoerythrin which in conditions of nutrient deficiency is quickly mobilized and used to sustain growth (Nagler et al., 2003; Hernández et al., 2006). This ability can constitute a competitive advantage over green macroalgae during periods of low nitrogen availability (Comín et al., 1995). Before 1998, the mean ammonium value in the water column was $28.15 \mu \mathrm{mol} \mathrm{L}^{-1}$, which means that ammonium uptake could be enough to maintain the internal nitrogen content above the critical tissue concentrations for maximum growth (1.5\% DW for nitrogen according to Duarte, 1992). It seems possible that Gracilaria gracilis had lower biomass before the management due to shading by the green macroalgal mats lying above (Hernández et al., 1997). Also, during the growth seasons red macroalgae biomass increased after green macroalgae started to decrease and in years when there was an absence of blooms, G. gracilis biomass was higher, which seems to support this hypothesis. The fact that $G$. gracilis settles to the sediment may play an important role in nutrient acquisition and may be a competitive advantage since they can partially intercept nutrients released from the sediment that otherwise would enter the water column (Lavery and McComb, 1991; Menéndez and Comín, 2000). In this way, red macroalgae would have more ammonium available than green macroalgae after the management and would need to take up less oxidized forms, saving energy to maintain a high growth rate. Also, with the reduction of green biomass, light was more accessible to red macroalgae thus enhancing ammonium uptake and growth.

Seagrass species seem to be adapted to nitrogen-poor environments as they are able to maintain high production rates with relatively low nitrogen availability in the water column (Pedersen and Borum, 1992; Bocci et al., 1997; van Katwijk et al., 1997). This is possible due to an efficient uptake of nutrients from the water column and sediment pore water and to a mechanism of conservation, where older leaves act as nutrient sinks which afterwards are translocated to more actively growing and nutrient demanding tissues (Pedersen and Borum, 1992). Nutrients are taken up directly from the water column through leaves and from the sediment pore water through roots (Zimmerman et al., 1987; Hemminga et al., 1994; Bocci et al., 1997; Hemminga, 1998; Sfriso and Marcomini, 1999) but with differences in uptake (Rubio et al., 2005). Sediments are considered the primary nutrient source for seagrass roots, yet they may not have the capacity to support total nutrient requirements seeing as the uptake can be limited by diffusion (Touchette and Burkholder, 2000). In this way, leaf uptake represents an important contribution to nutrient supply. Leaves can take up both $\mathrm{NH}_{4}^{+}$and $\mathrm{NO}_{3}^{-}$, whereas roots take up mostly $\mathrm{NH}_{4}^{+}$since it is the prevalent form in the sediments (Bocci et al., 1997). Nonetheless, aboveground tissues present a higher uptake affinity for $\mathrm{NH}_{4}^{+}$than roots and they seem to be more efficient in removing low levels of this reduced form (Pedersen 
and Borum, 1992; Hemminga et al., 1994; Touchette and Burkholder, 2000). Considering that aboveground tissues are more sensible to light availability than belowground (Pèrez et al., 1994) and that they have an important function in nutrient absorption and in photosynthesis, seagrass would have suffered greatly from the presence of Ulva spp. mats. With the disappearance of the green blooms, light limitation was reversed and the inhibition on Zostera noltii eliminated. The decrease in internal $\mathrm{N}$ concentrations in the leaves after 1998 is possibly a combined result of ammonium reduction in the water column and a dilution effect due to increased biomass production.

Seagrass show a phosphate affinity in the same order of magnitude as for ammonium (Romero et al., 2006) and they tend to take up $\mathrm{PO}_{4}^{3-}$ mainly through the leaves, relying on root uptake only when it is negligible in the water column (Brix and Lyngby, 1985; Touchette and Burkholder, 2000). This would explain the increase in tissue $\mathrm{P}$ concentrations in both roots and leaves with the significant increase in DIP in the water column after the management actions were implemented.

\section{Conclusion}

The combined actions taken to reduce eutrophication symptoms in the South arm of the Mondego system have led to ecological changes within primary producer assemblages, namely: the beginning of Zostera noltii beds recovery, the increase of Gracilaria gracilis biomass, the absence of green macroalgal blooms, whilst phytoplankton biomass did not change. Therefore, since one action can cause different responses, it is important to try to understand what changes can be expected when management plans are implemented in the ecosystems.

\section{References}

Bocci, M., Coffaro, G., Bendoricchio, G., 1997. Modelling biomass and nutrient dynamics in eelgrass (Zostera marina L.): applications to the Lagoon of Venice (Italy) and Øresund (Denmark). Ecological Modelling 102, 67-80.

Boyer, K., Fong, P., 2005. Macroalgal-mediated transfers of water column nitrogen to intertidal sediments and salt marsh plants. Journal of Experimental Marine Biology and Ecology 321, 59-69.

Brix, H., Lyngby, J.E., 1985. Uptake and translocation of phosphorus in eelgrass (Zostera marina). Marine Biology 90, 111-116.

Brun, F.G., Hernández, I., Vergara, J.J., Peralta, G., Pérez-Lloréns, J.L., 2002. Assessing the toxicity of ammonium pulses to the survival and growth of Zostera noltii. Marine Ecology Progress Series 225, 177-187.

Cohen, R.A., Fong, P., 2004. Nitrogen uptake and assimilation in Enteromorpha intestinalis (L.) Link (Chlorophyta): using ${ }^{15} \mathrm{~N}$ to determine preference during simultaneous pulses of nitrate and ammonium. Journal of Experimental Marine Biology and Ecology 309, 67-77.

Collos, Y., 1998. Nitrate uptake, nitrite release and uptake, and new production estimates. Marine Ecology Progress Series 171, 293-301.

Comín, F.A., Martin, M., Menendez, M., Romero, J.A., Herrera-Silveira, J.A., 1995. Integrated management of a coastal lagoon in the Ebro DeltaProceedings of the Second International Conference on the Mediterranean Coastal Environment, MEDCOAST" 95. Geojournal 34, 883-895. Springer, Netherlands.
Duarte, C.M., 1992. Nutrient concentration of aquatic plants: patterns across species. Limnology and Oceanography 37, 882-889.

Emery, N.C., Ewanchuk, P.J., Bertness, M.D., 2001. Competition and saltmarsh plant zonation: stress tolerators may be dominant competitors. Ecology 82, 2471-2485.

Flindt, M.R., Neto, J.M., Amos, C.L., Pardal, M.A., Bergamasco, A., Pedersen, C.B., Andersen, F.Ø., 2004. Plant bound nutrient transport. Mass transport in estuaries and lagoons. In: Nielsen, S.L., Banta, G.T., Pedersen, M.F. (Eds.), The Influence of Primary Producers on Estuarine Nutrient Cycling: the Fate of Nutrient Biomass. Series: Aquatic Ecology, vol. 2. Kluwer Academic Press, pp. 93-128.

Fong, P., Fong, J.J., Fong, R.C., 2004. Growth, nutrient storage, and release of dissolved organic nitrogen by Enteromorpha intestinalis in response to pulses of nitrogen and phosphorus. Aquatic Botany 78, 83-95.

Fujita, R.M., 1985. The role of nitrogen status in regulating transient ammonium uptake and nitrogen storage by macroalgae. Journal of Experimental Marine Biology and Ecology 92, 283-301.

Glenn, E.P., Moore, D., Akutagawa, M., Himler, A., Walsh, T., Nelson, S.G., 1999. Correlation between Gracilaria parvispora (Rhodophyta) biomass production and water quality factors on a tropical reef in Hawaii. Aquaculture $178,323-331$

Hanisak, M.D., 1979. Nitrogen limitation of Codium fragile ssp. tomentosoides as determined by tissue analysis. Marine Biology 50, 333-337.

Havens, K.E., Hauxwell, J., Tyler, A.C., Thomas, S., McGlathery, K.J., Cebrian, J., Valiela, I., Steinman, A.D., Hwang, S.-J., 2001. Complex interactions between autotrophs in shallow marine and freshwater ecosystems: implications for community responses to nutrient stress. Environmental Pollution 113, 95-107.

Hayden, H.S., Blomster, J., Maggs, C.A., Silva, P.C., Stanhope, M.J., Waaland, J.R., 2003. Linnaeus was right all along: Ulva and Enteromorpha are not distinct genera. European Journal of Phycology 38, 277-294.

Hein, M., Pedersen, M.F., Sand-Jensen, M., 1995. Size dependent nitrogen uptake in micro-and macroalgae. Marine Ecology Progress Series 118, 247-253.

Hemminga, M.A., 1998. The root/rhizome system of seagrasses: an asset and a burden. Journal of Sea Research 39, 183-196.

Hemminga, M.A., Koutstaal, B.P., van Soelen, J., Merks, A.G.A., 1994. The nitrogen supply to intertidal eelgrass (Zostera marina). Marine Biology $118,223-227$

Hernández, I., Peralta, G., Pérez-Lloréns, J.L., Vergara, J.J., Niell, F.X., 1997. Biomass and dynamics of growth of Ulva species in Palmones River Estuary. Journal of Phycology 33, 764-772.

Hernández, I., Martínez-Aragón, J.F., Tovar, A., Pérez-Lloréns, J.L., Vergara, J.J., 2002. Biofiltering efficiency in removal of dissolved nutrients by three species of estuarine macroalgae cultivated with sea bass (Dicentrarchus labrax) waste waters 2. Ammonium. Journal of Applied Phycology 14, 375-384.

Hernández, I., Pérez-Pastor, A., Vergara, J.J., Martínez-Aragón, J.F., Fernández-Engo, M.A., Pérez-Lloréns, J.L., 2006. Studies on the biofiltration capacity of Gracilariopsis longissima: from microscale to macroscale. Aquaculture 252, 43-53.

Jones, A.B., Dennison, W.C., Preston, N.P., 2001. Integrated treatment of a shrimp effluent by sedimentation, oyster filtration and macroalgal absorption: a laboratory scale study. Aquaculture 193, 155-178.

Kautsky, L., 1982. Primary production and uptake kinetics of ammonium and phosphate by Enteromorpha compressa in an ammonium sulphate industry outlet area. Aquatic Botany 12, 23-40.

Kraemer, G.P., Hanisak, M.D., 2000. Physiological and growth responses of Thalassia testudinum to environmentally-relevant periods of low irradiance. Aquatic Botany 67, 287-300.

van Katwijk, M.M., Vergeer, L.H.T., Schmitz, G.H.W., Roelofs, J.G.M., 1997. Ammonium toxicity in eelgrass Zostera marina. Marine Ecology Progress Series 157, 159-173.

Lartigue, J., Sherman, T.D., 2005. Response of Enteromorpha sp. (Chlorophyceae) to a nitrate pulse: nitrate uptake, inorganic nitrogen storage and nitrate reductase activity. Marine Ecology Progress Series 292, 147-157.

Lavery, P.S., McComb, A.J., 1991. Macroalgal-sediment nutrient interactions and their importance to macroalgal nutrition in a eutrophic estuary. Estuarine, Coastal and Shelf Science 32, 281-295. 
Levine, J.M., Brewer, J.S., Bertness, M.D., 1998. Nutrients, competition and plant zonation in a New England salt marsh. Journal of Ecology 86, 285-292.

Lillebø, A.I., Neto, J.M., Martins, I., Verdelhos, T., Leston, S., Cardoso, P.G., Ferreira, S.M., Marques, J.C., Pardal, M.A., 2005. Management of a shallow temperate estuary to control eutrophication: the effect of hydrodynamics on the system nutrient loading. Estuarine, Coastal and Shelf Science 65, 697-707.

Lillebø, A.I., Teixeira, H., Pardal, M.A., Marques, J.C., 2007. Applying water quality status criteria to a temperate estuary (Mondego, Portugal) before and after the mitigation measures to reduce eutrophication symptoms. Estuarine, Coastal and Shelf Science 72, 177-187.

Limnologisk Metodik, 1992. Ferskvandsbiologisk Laboratorium, Københavns Universitet (Ed.). Akadmisk Forlag, Københavns, 172 pp.

Maier, C.M., Pregnall, A.M., 1990. Increased macrophyte nitrate reductase activity as a consequence of groundwater input of nitrate through sandy beaches. Marine Biology 107, 263-271.

Menéndez, M., Comín, F.A., 2000. Spring and summer proliferation of floating macroalgae in a Mediterranean coastal lagoon (Tancada lagoon, Ebro Delta, NE Spain). Estuarine, Coastal and Shelf Science 51, 215-226.

Menéndez, M., Martínez, M., Comín, F.A., 2001. A comparative study of the effect of $\mathrm{pH}$ and inorganic carbon resources on the photosynthesis of three floating macroalgal species of a Mediterranean coastal lagoon. Journal of Experimental Marine Biology and Ecology 256, 123-136.

Mistri, M., Rossi, R., Fano, E.A., 2001. Structure and secondary production of a soft bottom macrobenthic community in a brackish lagoon (Sacca di Goro, north-eastern Italy). Estuarine, Coastal and Shelf Science 52, 605-616.

Nagler, P.M., Glenn, E.P., Nelson, S.G., Napolean, S., 2003. Effects of fertilization treatment and stocking density on the growth and production of the economic seaweed Gracilaria parvispora (Rhodophyta) in cage culture at Molokai, Hawaii. Aquaculture 219, 379-391.

Nedwell, D.B., Sage, A.S., Underwood, G.J.C., 2002. Rapid assessment of macro algal cover on intertidal sediments in a nutrified estuary. Science of the Total Environment 285, 97-105.

Parsons, T.R., Maita, Y., Lally, C.M., 1985. Pigments. In: A Manual of Chemical and Biological Methods for Seawater Analysis. Pergamon Press, pp. 101-104.

Peckol, P., Rivers, J.S., 1996. Contribution by macroalgal mats to primary production of a shallow embayment under high and low nitrogen-loading rates. Estuarine, Coastal, and Shelf Science 43, 311-325.

Pedersen, M.F., Borum, J., 1997. Nutrient control of estuarine macroalgae: growth strategy and the balance between nitrogen requirements and uptake. Marine Ecology Progress Series 161, 155-163.

Pedersen, M.F., Borum, J., 1992. Nitrogen dynamics of eelgrass Zostera marina during a late summer period of high growth and low nutrient availability. Marine Ecology Progress Series 80, 65-73.

Pennings, S.C., Stanton, L.E., Brewer, J.S., 2002. Nutrient effects on the composition of salt marsh plant communities along the Southern Atlantic and Gulf coasts of the United States. Estuaries 25, 1164-1173.

Pèrez, M., Duarte, C.M., Romero, J., Sand-Jensen, K., Alcoverro, T., 1994. Growth plasticity in Cymodocea nodosa stands: the importance of nutrient supply. Aquatic Botany 47, 249-264.

Raffaelli, D.G., Raven, J.A., Poole, L.J., 1998. Ecological impact of green macroalgal blooms. Oceanography and Marine Biology: An Annual Review 36, 97-125.

Raven, J.A., Taylor, R., 2003. Macroalgal growth in nutrient enriched estuaries: a biogeochemical and evolutionary perspective. Water, Air, and Soil Pollution 3, 7-26.

Romero, J., Lee, K.-S., Pérez, M., Mateo, M.A., Alcoverro, T., 2006. Nutrient dynamics in seagrass ecosystems. In: Larkum, A.W.D., et al. (Eds.),
Seagrasses. Biology, Ecology and Conservation. Springer, Netherlands, pp. 227-254.

Rosenberg, G., Ramus, J., 1984. Uptake of inorganic nitrogen and seaweed surface-area: volume ratios. Aquatic Botany 19, 65-72.

Rubio, L., Linares-Rueda, A., García-Sánchez, M.J., Fernández, J.A., 2005. Physiological evidence for a sodium-dependent high-affinity phosphate and nitrate transport at the plasma membrane of leaf and root cells of Zostera marina L. Journal of Experimental Botany 56, 613-622.

Runcie, J.W., Ritchie, R.J., Larkum, A.W.D., 2003. Uptake kinetics and assimilation of inorganic nitrogen by Catenella nipae and Ulva lactuca. Aquatic Botany 76, 155-174.

Sand-Jensen, K., Borum, J., 1991. Interactions among phytoplankton, periphyton, and macrophytes in temperate freshwater and estuaries. Aquatic Botany 41, 137-175.

Sfriso, A., Marcomini, A., 1999. Macrophyte production in a shallow coastal lagoon: part II. Coupling with sediment, SPM and tissue carbon, nitrogen and phosphorus concentrations. Marine Environmental Research 47, 285-309.

Strickland, J.D.H., Parsons, T.R., 1972. A Practical Handbook of Seawater Analysis. In: Fisheries Research Board of Canada Bulletin, vol. 167, second ed., Ottawa, pp. 310.

Taylor, D., Nixon, S., Granger, S., Buckley, B., 1995. Nutrient limitation and the eutrophication of coastal lagoons. Marine Ecology Progress Series 127, 235-244.

Teixeira, H., Salas, F., Pardal, M.A., Marques, J.C., 2007. Applicability of ecological evaluation tools in estuarine ecosystems: the case of the lower Mondego estuary (Portugal). Hydrobiologia 587, 101-112.

Touchette, B.W., Burkholder, J.M., 2000. Review of nitrogen and phosphorus metabolism in seagrasses. Journal of Experimental Marine Biology and Ecology 250, 133-167.

Turpin, D.H., Elrifi, I.R., Birch, D.G., Weger, H.G., Holmes, J.J., 1988. Interactions between photosynthesis, respiration, and nitrogen assimilation in microalgae. Canadian Journal of Botany 66, 2083-2097.

Valiela, I., Foreman, K., LaMontagne, M., Hersh, D., Costa, J., Peckol, P., DeMeo-Andreson, B., D’Avanzo, C., Babione, M., Sham, C., Brawley, J., Lajtha, K., 1992. Couplings of watersheds and coastal waters: sources and consequences of nutrient enrichment in Waquoit Bay, Massachusetts. Estuaries 15, 443-457.

Valiela, I., McClelland, J., Hauxwell, J., Behr, P.J., Hersh, D., Foreman, K., 1997. Macroalgal blooms in shallow coastal estuaries: controls and ecophysiological and ecosystem consequences. Limnology and Oceanography $42,1105-1118$.

Valiela, I., Bowen, J.L., 2007. Nitrogen sources to watersheds and estuaries: role of land cover mosaics and losses within watersheds. Environmental Pollution 118, 239-248.

Viaroli, P., Naldi, M., Bondavalli, C., Bencivelli, S., 1996. Growth of the seaweed Ulva rigida C. Agardh in relation to biomass densities, internal nutrient pools and external supply in the Sacca di Goro lagoon (Northern Italy). Hydrobiologia 329, 93-103.

Webster, I.T., Harris, G.P., 2004. Anthropogenic impacts on the ecosystems of coastal lagoons: modelling fundamental biogeochemistry process and management implications. Marine and Freshwater Research 55, 67-78.

Zhang, J., Jørgensen, S.E., Beklioglu, M., Ince, O., 2003. Hysteresis in vegetation shift - lake Mogan prognoses. Ecological Modelling 164, 227-238.

Zimmerman, R.C., Smith, R.D., Alberte, R.S., 1987. Is growth of eelgrass nitrogen limited? A numerical simulation of the effects of light and nitrogen on the growth dynamics of Zostera marina. Marine Ecology Progress Series 41, 167-176. 